\title{
The constitution of hydrosocial power: agribusiness and water scarcity in Ica, Peru
}

\author{
Gerardo H. Damonte ${ }^{1,2}$
}

\begin{abstract}
During the 2000s, the Ica region, located on the Peruvian coast, gained notoriety as the main stage of what the media and politicians called the "agricultural export miracle." The exponential growth of nontraditional exports that ensued, along with the rising importance of the agroindustry in generating foreign currency, led to the emergence of an agribusiness elite as an important new social actor. Through a range of strategies aimed at consolidating and expanding its power over state and nonstate actors, the agribusiness elite has been able to overexploit scarce groundwater resources in the pursuit of economic growth without opposition. Thus, the question that guides this article is, how did the agribusiness elite secure access to valuable groundwater resources to the verge of depletion despite the attempts of regional and local authorities to regulate water use? Based on a political ecology perspective, I argue that a political settlement between the agribusiness elite, certain state sectors, and local actors, based on a shared neoliberal development discourse, has laid the foundations for the agribusiness elite to concentrate its hydropower in the region. In developing this argument, I analyze the elite's strategies to reproduce the different dimension of hydropower as well as the fragmented and sometimes contradictory political positioning of different state agencies. This article contributes to the literature by unpacking the extractivist state and the elite's strategies to reproduce its hydrosocial power.
\end{abstract}

Key Words: agribusiness; elites; Ica; Peru; political settlements; power; state policies; water governance; water scarcity

\section{INTRODUCTION}

During the 2000s, the Ica region, located on the Peruvian coast, gained notoriety as the main stage of what the media and politicians called the "agricultural export miracle." This miracle occurred through the greening of large extensions of desert land using modern agricultural techniques. The exponential growth of nontraditional exports that ensued, along with the rising importance of the agroindustry in generating foreign currency, led to the emergence of an agribusiness elite comprising the owners of the principle export firms. These developments have considerably changed the socio-political landscape in the region.

After a few years, the so-called miracle became endangered by its own success. The extensive production of export crops implied the overexploitation of the Ica, Villacurí, and Lanchas aquifer, triggering a decrease in groundwater levels and resulting in water scarcity affecting many different users across the region (Oré et al. 2012, Marshall 2014). In response to this situation, the regional government restricted the drilling of new underground wells for agricultural use, banning them altogether in 2005. This ban was endorsed, extended, and strengthened on different occasions as part of efforts by the National Water Authority (Autoridad Nacional de Agua or ANA) to halt the overexploitation of the aquifer and manage its recovery. However, the ANA faced serious difficulties when attempting to monitor and sanction the irregular operations of the main users of groundwater, i.e., the agribusiness elite (Muñoz 2015). This situation arose because of an imbalance of power in which the agribusiness elite successfully positioned itself as the dominant political and economic actor in the region (Damonte 2015, Damonte and Gonzales 2018, Damonte and Boelens 2019).

Groundwater scarcity represents a major problem for all agricultural producers as well as for the urban population in the region. Water levels have decreased dramatically in the aquifers that are now in danger of salinization because of overexploitation.
Groundwater is of higher quality and its flows can be better regulated than surface water from the Ica River, hence all users seek to gain access to the aquifers. However, the infrastructure required to do so is costly and is mostly only accessible by largescale agricultural export companies. In spite of this asymmetrical access to water resources, public resistance or opposition to agroindustry remains low among small and medium farmers. And although many agricultural export companies do not comply with state regulations to conserve water resources, most state sectors continue to support the expansion of agricultural exports.

How did the agribusiness elite secure access to valuable groundwater resources to the verge of depletion regardless of the regulatory efforts of the local water authorities (Autoridades Locales de Agua or ALAs)? In answering this question, I argue that a political settlement between the agribusiness elite, some states actors, and local water users' associations (WUAs) has created the conditions for the agribusiness elite to consolidate and sustain its hydrosocial power in order to gain almost unrestricted access to groundwater.

The promotion of a neoliberal extractive model of development by the central government since the 1990s has produced shared interest between the state agricultural and economic sectors and the emerging agribusiness elites. In Ica this coalition has evolved into a political settlement that has incorporated other agricultural producers with the aim of securing political stability and controlling the regional political agenda. Within this scenario, the agribusiness elite has been able to increase groundwater extraction and production, while allowing the central government to preserve the "agricultural export miracle," at least in the short term. Therefore, the agricultural export companies continue to deplete the aquifers, considered the most relentlessly exploited and damaged in the whole country (ANA 2018), while access to groundwater remains unequal. 
The situation in Ica is similar to other cases across the world where powerful agricultural export companies capture water resources to the detriment of smaller producers and city dwellers (Bakker 2010, Duarte-Abadía et al. 2015, Hendriks and Boelens 2016, Hommes and Boelens 2017). In addition, the Ica case exemplifies the way extractive corporations have gained, with state support, access to local resources at a time of scarcity in the region and throughout Peru (Bebbington and Williams 2008, Hoogesteger and Verzij1 2015, Hoogesteger et al. 2016). I focus the analysis on the strategies used by the agribusiness elite to establish a political settlement to control groundwater resources. These strategies refer to the dominant actors' ability to produce and reproduce "hydropower" through the exercise of three power dimensions: economic capacity, technical knowledge, and coercion. Following a tradition of scholarship that emphasizes the heterogeneous nature of the state, this article's contribution to the literature is twofold: first, it disentangles the extractivist state and second, it provides a detailed analysis of the different strategies used by the elite to control scarce water resources.

I draw on evidence from an interdisciplinary research project on state policies and water scarcity. Primary data was collected over 45 days between August and September 2015 in the Valley of Ica and Pampas de Villacurí, through observations and 28 group and individual interviews with central government, regional and district authorities, independent smallholder farmers, agricultural export companies, and representatives of WUAs and groundwater user boards (GUBs, established by the agribusinesses). We conducted structured and semistructured interviews and analyzed them using thematic-content and narrative methods. Secondary data was collected from sources that included academic publications, government reports, publicly available videos, newspapers, national legal frameworks, and maps. The period of the analysis spans from the 1990s to 2015.

\section{CONCEPTUAL FRAMEWORK}

\section{Political settlement}

Political settlement theory refers to the arrangement between elites to generate a fundamental order and stability on which the state can be founded and function (DFID 2010, Khan 2000, Bebbington et. al. 2017, Sanborn et al. 2017). Political scientists have used the concept to analyze and explain differences in political institutions and the birth of modern states, defining the term as "the forging of a common understanding, usually between political elites, that their best interests or beliefs are served through acquiescence to a framework for administering political power" (John and Putzel 2009:4). I use the concept to describe the political coalition made between the owners of agricultural export firms and the Peruvian Ministries of Agriculture and Economy as a way of promoting an export-based development model in the agricultural sector. In Ica, this political settlement has enabled agricultural export businesses to increase production through unregulated access to ground water.

According to John and Putzel (2009), the political settlement can be observed in the structure of property rights and entitlements, on the one hand, and in the regulatory structure of the state on the other. In Ica, the political settlement is manifest in the structure of land ownership, in state regulations around groundwater extraction for agribusiness, and in the power of the agribusiness elite to avoid these regulations.
Political settlements are reached through a process of negotiation between different actors, including state agencies. Therefore, the state is not considered a monolithic entity but as an arena of contention where different actors and sectors struggle for power (Migdal 1988). In the case of Ica, the political settlement includes some state sectors, primarily the national Ministries of Agriculture and Economy, while excluding others including environmental agencies within central government and regional agencies responsible for regulating water. This particular political settlement has driven economic growth and it has achieved this by undermining official regulations.

Political settlements may be more stable or unstable depending on the characteristics of the "patron-client organization and structure" of the coalition (Khan 2010:36, unpublished manuscript, https://eprints.soas.ac.uk/9968/1/Political Settlements internet.pdf). More inclusive settlements, which incorporate a larger range of actors, tend to be more stable than exclusive ones where competition for power could emerge from excluded elites. Likewise, the vertical distribution of power, that is, the power balance between higher and lower factions within the coalitions, may also affect stability. Furthermore, the greater the power of higher over lower factions, the greater the top-down enforcement within the coalition and vice versa (Khan 2010, unpublished manuscript). Indeed, in Ica the inclusion of locally powerful WUAs into the political settlement has provided stability to the coalition by providing a mechanism for the elite to suppress opposition.

\section{Hydrosocial power}

In his classic work Oriental Despotism, Wittfogel (1957) explains how in agrarian societies, states have typically exercised their power through control over water resources. For the author, states have increasingly concentrated their power through building and managing irrigation mostly in semiarid ecosystems. There has been several critiques of Oriental Despotism for its environmental determinism in defining hydraulic societies (Livingston 2011) and its technological determinism in associating irrigation systems with authoritarian political rule (Mitchell 1973, Davies 2009). However, other studies have traced a continuity with Wittfogel's dialectical understanding of human societies in relation with water by, for example, developing the concept of the hydrosocial cycle (Budds et al. 2014, Bichsel 2016). Following this dialogical understanding, I identify hydrosocial power through the interaction between power and water control.

Moreover, recent studies have explored the relationship between control over water and the concentration of power by examining case studies where water resources are managed by private firms (Oré and Muñoz 2018). As such, the concept of hydrosocial power can be broadened to include nonstate actors. Other studies have shown how corporations such as transnational drinking water companies (Bakker 2010, Swyngedouw 2004, 2006, Hommes and Boelens 2017), agroindustrial firms (Worster 1985, Peña 2011, Oré and Damonte 2014, Damonte 2015, Urteaga-Crovetto 2016), mining and hydrocarbon industries (Perreault 2007, 2013, Bebbington and Williams 2008), and hydro-electrical companies (Yacoub et al. 2015) have gained control over water resources to the detriment of less politically powerful actors.

In the case of Ica, a coalition between the agribusiness and government elite along with some local actors has developed strategies to increase its control over scarce groundwater 
resources. That is, the coalition has increased its hydrosocial power through the exercise of three interrelated dimensions of power: economic capacity, technical knowledge, and coercive capacity.

\section{Economic capacity}

Economic capacity refers to the availability of the financial capital necessary to acquire the means of production and labor force and to generate profit. In terms of agricultural exports in Ica, the principal means of production are land and groundwater, as well as the technology and infrastructure necessary for accessing these resources, for example, boreholes, drip and sprinkler irrigation systems, and large-scale water infrastructure. In a context where access to groundwater is conditioned by the financial capital of its users, economic capacity translates into hydrosocial power that is accumulated by and concentrated in few hands.

\section{Technical knowledge}

The author's understanding of technical knowledge as a form of control is based on Foucault's (1992) writings on truth as a mechanism of power. From a poststructural perspective, Foucault analyzes how hegemonic discourses and their espousers elevate themselves over other forms of discourse and actors, thereby claiming the right to name and classify things. In the case of water, the techno-scientific approach has become hegemonic and is manifest in discourses around efficiency and rationality that both legitimize the economic valuation of water while sidestepping other kinds of use and value (Boelens et al. 2006, Boelens 2011, Yacoub et al. 2015). The notion of knowledge-power reveals the importance of the production of knowledge to legitimize certain views, approaches, and actions, and to create objects of intervention with the purpose of establishing control (Foucault 2006, Agrawal 2005). In Ica, the agribusiness elite have shaped a discourse around water efficiency to position themselves as leaders above the government and other producers. This selflegitimization enables the elite to justify their priority position and control of water resources.

\section{Coercive capacity}

Coercive capacity is understood as the ability of certain actors to constrain the behavior of others through repressive means (Bourdieu and Passeron 2001, Springer 2012). In Ica, coercion is exerted by the agribusiness elite through the threat of physical violence, by discrediting or damaging an individual's reputation, or by hampering government and civil society attempts to monitor and regulate.

This conceptual framework highlights two key characteristics of groundwater scarcity in Ica. First, the political settlement between certain state sectors and agricultural export elites has laid the foundation for private water control through strategies that contravene official regulations and undermine government institutional power. Second, this political settlement has created a favorable realm for agribusiness elites to establish and sustain multidimensional power structures that facilitate control over scarce resources.

\section{POLITICAL COALITIONS AND THE EXERCISE OF HYDROSOCIAL POWER FOR GAINING CONTROL OVER GROUNDWATER IN ICA}

In the 20th century, Peru has witnessed dramatic social and political changes that have led to increasing water shortage mainly on the coastal regions that receive only $2 \%$ of the naturally available water in the country. Social transformations and political conflicts triggered processes of migration and displacement from the highlands to the main cities located in the coastal regions. In addition, main industries and agribusiness have flourished in such regions, increasing the demand for water resources. Urbanization and economic growth have laid the foundation for water scarcity in the coastal regions such as Ica.

During the first half of the 20th century, haciendas flourished in the Ica region where they mainly produced cotton for global markets (Oré 2006). The owners of these plantations were part of the Peruvian oligarchy that constituted the ruling elite. In the 1970s, a military regime expropriated and redistributed the land belonging to the haciendas during a process of land reform that shattered the oligarchy's rule (Matos and Mejia 1980). In Ica, the government distributed expropriated land to new state-sponsored agricultural cooperatives that grouped together former hacienda workers. Over the next decade, workers dismantled the cooperatives and divided the land among themselves to become individual producers (Oré and Damonte 2014). During this whole period, water was first managed by the hacienda owners, then by the cooperatives and finally by water user organizations. No new powerful elite was formed after the fall of oligarchic rule in the region.

Since the 1990s, the Peruvian state has enacted different water management laws to regulate the relationship between state agencies and water users. During this decade the main water user organizations in Ica were the Junta de Usuarios del Rio Ica (JUDRI) and the Junta de Usuarios de Riego de La Achirana Santiago de Chocorvos (JURLASCH). These water user organizations mainly grouped together small and medium sized farmers and were responsible for coordinating the management of irrigation water from the Ica River and the La Achirana channel with state water authorities. Since the turn of the century, these water associations have witnessed the gradual settlement of agricultural export companies in the region. These new businesses have increased the quantity and quality of agricultural export production by dramatically expanding irrigation across existing and new areas using groundwater supplies.

In 2008, the central government set up a new institutional structure for water management with the national water authority (ANA) at the top of the system and local water authorities (ALA) at the bottom. Currently, the ANA officially operates as an independent institution that forms part of the Ministry of Agriculture. There are two ALAs in the Ica region: the ALA-Ica and the ALA-Río Seco.

This institutional reform has empowered local government agencies by granting them the capacity for political decision making and access to state resources (Oré and Geng 2014). Against this backdrop, the agricultural export elite established two groundwater user boards: the Junta de Usuarios de Agua Subterránea del Valle de Ica (JUASVI) and the Junta de Usuarios de Agua Subterránea de Río Seco (JURS). The GUBs are less open than the WUAs in that they have fewer members, and have become the most powerful water organizations in Ica.

Currently the main actors in water politics in Ica are the WUAs, representing small and medium-sized local farmers, the GUBs, which represent the agricultural export companies, and the state, represented by national and regional water authorities (the ANA 
and ALAs) and central state authorities. The Ministries of Economy and Agriculture wield particular influence in the region because they are responsible for approving large-scale infrastructure projects and for establishing regulatory frameworks. The agribusiness elite in Ica are global political players; they have transnational financial interests, significant political presence within central and regional government, and maintain a powerful local presence through the GUBs.

\section{Political settlement of water management}

The current situation in Ica constitutes a political settlement with a clearly dominant actor, the agribusiness elite, which upholds its interests through various means. The agribusiness elite encompasses transnational companies and national enterprises owned by members of the country's old and new economic elite. The political pact includes authorities and technocrats from the central state's agencies and the regional government. Both entrepreneurial and state actors promote a market economy that privileges large-scale production and extraction for the global market over other development alternatives. The political settlement is based on a shared ideology: a neoliberal extractive model of development in which private interests trump state regulatory authority in the name of economic growth.

An illustrative example of this shared vision for national development through extractivism is the role of the regional Governor of Ica who has made the promotion of agroindustry the platform for his political career. In an interview with the national newspaper $\mathrm{El}$ Comercio, the Governor made the following comments about water shortages in Ica and their relation to agricultural productivity:

\section{(Journalist) It has been said at times that in Ica there won't be enough water to meet demand from the agricultural sector.}

(Governor) Well, a major constraint in Ica is water. Ica has a lot of arable land, which can't be farmed because of a lack of water. If we had more water, Ica could double its croplands with this 'super' agriculture, which is very modern, well-equipped and competitive. (Valz-Gen 2017)

According to this perspective, the employment, competitiveness, and profitability provided by "super" agriculture, i.e., the agricultural export industry, justify the extensive access to water resources enjoyed by this sector, in contrast to other types of agricultural production with no such virtues. This vision is supported by the affirmation that the agricultural export elite possesses superior technical knowledge and is therefore better able to manage scarce water resources.

Along the same lines, during a 2014 national cabinet meeting held in Ica, the Minister of Agriculture pledged S/. 650 million (US\$195 million) to water-related infrastructure, which he said would, "guarantee a continuous supply of water for agricultural production, thereby helping to sustain the agricultural export potential of Ica"[1]. No such investment was offered to support small and medium sized farmers who produce for the regional and national markets, despite this group representing the majority of farmers in Ica.

In addition, the political settlement in Ica has been furnished with a "revolving door" between agribusinesses and the national government, in particular the Ministry of Agriculture. In recent history, 11 out of 26 Ministers of Agriculture and Irrigation were directly or indirectly associated with large-scale agribusiness throughout Peru (see Table 1). Although these ministers have acted as board members, presidents, and consultants for important agricultural export firms, none of them has come from the smallholder agricultural sector.

As well as exerting its power in multiple ways, the agribusiness elite has also had to establish a sort of alliance with smaller farmers through their water users' associations. In order to do so, the JUASVI has provided technical support to the JURI and JURLASH for improving water infrastructure and legal advice in dealing with regulatory issues. In return, the water user associations have supported, or at least not opposed, the agribusiness elite's control over groundwater resources.

In forming this alliance, the agribusiness elite acknowledges the historical importance of the JURI and JURSLASH as political actors with the ability to mobilize their members to influence political decisions, for example, advocating for the financing or (re)design of water infrastructure projects (Oré and Geng 2014). Indeed, WUAs in Ica have been very active in demanding changes to state-sponsored projects to restore the aquifer because it was felt these would only benefit the agricultural export companies.

Although the agribusiness elite cite the positive impacts of agroindustrial farming for economic development to demand water for their lands, it has become clear that in isolation no significant progress could be made in terms of infrastructure in the region. In this context, negotiating with the WUAs was necessary to bring them into the pact. As a result, the political settlement in Ica has been broadened beyond just the elite and state actors.

By incorporating the WUAs into the political settlement, the agricultural export sector has been able to pursue its goals without facing opposition. The capacity of the elite to enforce their decisions on lower factions in the political coalition relates to their capacity to concentrate and legitimate hydropower. Yet this is only part of the story.

Central state authorities have systematically undermined the ALAs' efforts to regulate water use to benefit agricultural exports. As shall be explained, the agribusiness elite has accumulated the power not only to avoid state regulation but also to exercise violence against local government authorities. In practice, they have gained the power to freely extract water from the aquifer regardless of ecological concerns. Even scientific studies showing that that agribusiness is depleting valuable groundwater resources have not led to public unrest.

\section{The concentration, exercise, and legitimization of hydrosocial power in Ica}

In Ica, the agribusiness elite has used economic capacity, technical knowledge about water efficiency, and coercive capacity to consolidate power and control groundwater resources in a region with water scarcity.

\section{Economic capacity}

Along the coastal deserts of Peru agricultural production is intrinsically associated with the extraction of groundwater, the use of which was practically unregulated until 2009 when the 
Table 1. Relationship between Ministers of Agriculture and Irrigation and agroindustry (1990 2018).

\begin{tabular}{|c|c|c|c|}
\hline & Name & Links to agroindustry & President \\
\hline 1 & Carlos Amat and León Chávez & No & $\begin{array}{l}\text { Alberto Fujimori } \\
\quad(1990-2000)\end{array}$ \\
\hline 2 & Enrique Rossl Link & Unknown & \\
\hline 3 & Gustavo González Prieto & No & \\
\hline 4 & Absalón Vásquez Villanueva & Unknown & \\
\hline 5 & Rodolfo Muñante Sanguinetti & Unknown & \\
\hline 6 & Belisario De las Casas & Yes & \\
\hline 7 & José Chlimper Ackerman & Yes & \\
\hline 8 & Carlos Amat and León Chávez & No & $\begin{array}{l}\text { Valentín Paniagua } \\
\quad(2000-2001)\end{array}$ \\
\hline 9 & Álvaro Quijandría Salmón & Yes & $\begin{array}{l}\text { Alejandro Toledo } \\
\quad(2001-2006)\end{array}$ \\
\hline 10 & Francisco Gonzales García & Unknown & \\
\hline 11 & José León Rivera & Yes & \\
\hline 12 & Álvaro Quijandría Salmón & Yes & \\
\hline 13 & Manuel Manrique Ugarte & Unknown & \\
\hline 14 & Juan José Salazar García & Yes & $\begin{array}{l}\text { Alan García } \\
(2006-2011)\end{array}$ \\
\hline 15 & Ismael Benavides Ferreyros & Yes & \\
\hline 16 & Carlos Leyton Muñoz & No & \\
\hline 17 & Adolfo De Córdova Vélez & Unknown & \\
\hline 18 & Rafael Quevedo Flores & Yes & \\
\hline 19 & Jorge Villasante Araníbar & Unknown & \\
\hline 20 & Miguel Caillaux Zazzali & Yes & $\begin{array}{l}\text { Ollanta Humala } \\
\quad(2011-2016)\end{array}$ \\
\hline 21 & Luis Ginocchio Balcázar & Yes & \\
\hline 22 & Milton von Hesse La Serna & Unknown & \\
\hline 23 & Juan Manuel Benites Ramos & Unknown & \\
\hline 24 & José Manuel Hernández Calderón & Yes & $\begin{array}{l}\text { Pedro Pablo Kuczynski } \\
\quad(2016-2018)\end{array}$ \\
\hline 25 & José Arista Arbildo & Unknown & \\
\hline 26 & Gustavo Mostajo Ocola & Unknown & $\begin{array}{c}\text { Martín Vizcarra (2018- } \\
\text { present) }\end{array}$ \\
\hline 27 & Fabiola Muñoz Dodero & No & \\
\hline
\end{tabular}

Source: Ministry of Agriculture and Irrigation of Peru (https://www.gob.pe/minagri\#alta-direccion)

National Water Resources Law was enacted. Given that the installation of boreholes requires a great deal of financial investment, it was the large-scale agricultural export firms who most benefitted from Decree Law 65. This Decree enabled export firms to gain access to large areas of land for cultivating asparagus, grapes, and paprika.

Because of increasing international demand during the 2000s, land initially acquired by agricultural export firms became insufficient. As a result, large-scale farmers from the Valle de Ica decided to enlarge their properties through the purchase or leasing of adjacent plots of land from ex-cooperatives and small to medium-scale farmers. In contrast, property expansion in Villacurí was mostly achieved by acquiring barren lands (see Fig. 1). Between 1994 and 2012, while agricultural land ownership between 100 and 500 hectares increased by $19.67 \%$ in Ica, large sized properties of 500 hectares or more increased by $347.90 \%$ (INEI 1994, 2012).

Agricultural expansion put pressure on water availability in Ica and drove the search for additional groundwater sources. Increasing demand was met in different ways, either through the purchase of dilapidated wells that were subsequently repaired, the purchase of land with pre-existing wells in order to transfer extraction rights, or by drilling new boreholes (Damonte et al. 2014).

Unrestrained expansion of the agricultural frontier and widescale production of water-intensive crops depleted water levels in the aquifer of the Valley of Ica and Villacurí. In the 2000s, the agribusiness elite of Ica formed user committees (juntas de usuarios) to support the implementation of aquifer renovation projects by the central government. Meanwhile, the state, which was less interested in investing public funds in large-scale infrastructure projects, but keen on attracting private investments, devised a way of carrying out these projects. Hence, public-private associations (asociaciones público-privadas or APP) were born. Under this new model, water infrastructure projects were required to generate profit through the collection of payments from users. A user committee representative in Río Seco (JURS) Ica explains why this approach is appropriate:

... the state doesn't want to cover the whole cost of the project. It is really unlikely to do so and also, I think, personally, that we don't need to wait for the state to give us everything, especially given that we are a private export 
Fig. 1. Agricultural property expansion between 2011 and 2013 in Villacurí.

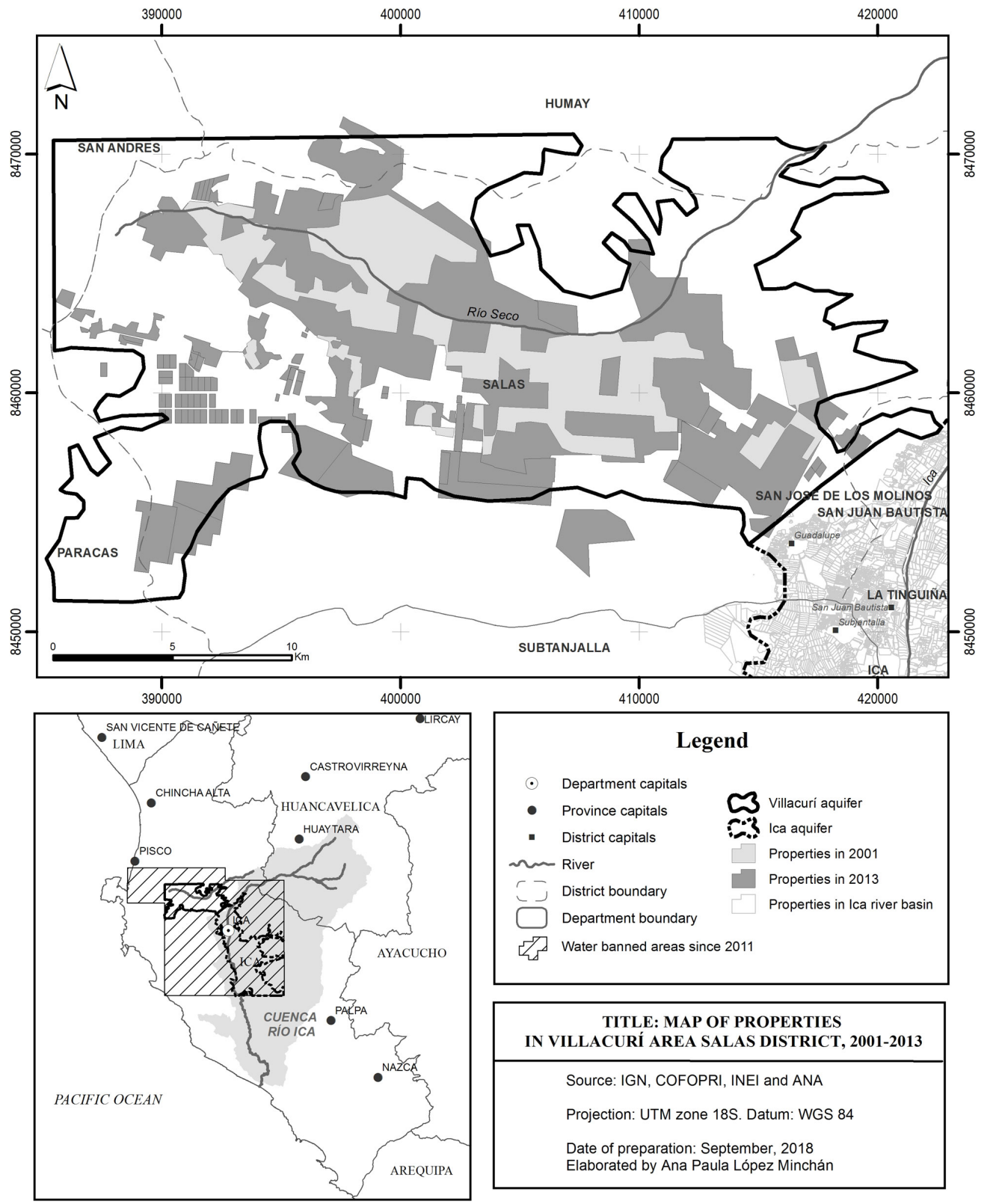

company. I am the one who is damaging the aquifer, I am overexploiting. So if my business has already depleted water resources, do I want the state to build the whole project for me?

The language used by the JURS official is one of responsibility and is based on the role that large water users play in the depletion of the aquifer. In fact, the APP not only aims to secure private support for infrastructure projects but also to ensure that agricultural export companies take responsibility for their actions in the pursuit of economic development. For example, the APP model requires private companies to demonstrate they are technically and financially capable of restoring aquifers through improved water management. Nevertheless, the execution of new infrastructure projects under the APP arrangement may provide a new way for the agribusiness elite to consolidate control over groundwater, by restricting access to those users who can afford the payments. Recently, these infrastructure projects have been under public scrutiny since the uncovering of corruption cases in relation to large infrastructure project biddings during the last decades in the country (Durand 2018).

"Knowledge-power" around water efficiency

The agricultural export sector in Ica has deployed a range of technology for efficient and rational use of water such as sprinkler and drip microirrigation systems. Water efficiency is understood 
by the private sector as using the least possible quantity of water to yield the largest possible output, and is thus associated mainly with economic rationality. As the JURS representative explains:

\begin{abstract}
Now Ica has given Peru a boost, positioning itself as the principal region for agricultural exports and drawing attention from the whole coastline from Tumbes to Tacna. The other regions said, "Why Ica and not us? Who is bigger?" But who was responsible? The government? No. Not this one, nor the previous one, nor the one before that. It was the private businessmen, the private sector. There was a center for wine making that had been left abandoned and the state did nothing, successive governments did nothing and (did) even less about irrigation.
\end{abstract}

The JURS official expresses a view shared among private businesses and civil servants, that the state is unable to efficiently manage water for agriculture production. Thus, only the private sector - thanks to its financial capacity and technical knowledge - can boost agricultural production. Given that there is a lack of public policy for regulating water use and that water resources are scarce in Ica, the installation of irrigation systems by agricultural exporters has been met with sympathy by the state, despite the fact that ongoing agricultural expansion means that overall water use has actually increased (ANA 2018).

Efficiency has therefore become a mere buzzword that has simply enabled the agribusiness elite to impose its interest over state and public concerns. The justification for this is that an "inefficient" state does not have the knowledge, and thus the right, to properly regulate the most "efficient" producers, i.e., the agroexport companies. This "knowledge-power" enables the agribusiness elite to act as experts on water management with a mandate to help "less efficient" producers such as the members of water user associations.

For example, in 2014 the groundwater users board JUASVI signed an agreement with the water user associations JURLACH and JUDRI to support them to clean and extend water canals and intakes. In exchange, the JURLACH and JUDRI authorized the GUB to use excess surface water for recharging the aquifer. As one official from the JUASVI explains:

\begin{abstract}
Surface water management involves many elements that have not been correctly dealt with by the relevant organizations, so we have had to get involved because surface water management can influence the aquifer recharge positively or negatively. So that's why we have been working since 2010 with more emphasis on supporting surface water management.
\end{abstract}

Again, the notion of responsibility can be found in the official's discourse, showing the extent to which efficiency and technological capacity have become valuable assets to agribusiness in Ica.

Their self-defined superior technical capacity and knowledge have positioned the agricultural export companies as the benchmark in groundwater management in the region. For example, the JUASVI was responsible for conducting one of the first water well surveys in Ica, even before the first government survey of 2007 , and for the creation of an open data system on precipitation and reservoir levels in the upper part of the watershed. The GUB has also executed its own aquifer recharge projects including the construction of 125 infiltration pools.

The GUBs in Ica are powerful social actors with sufficient authority to negotiate and set the agenda with the state. On more than one occasion, the JUASVI has attempted to carry out technical studies entrusted to the National Water Authority by negotiating interinstitutional cooperation agreements. These attempts, however, have not yet been successful because of resistance from individual officials who reject private meddling in public affairs. Notwithstanding, the data collected by JUASVI, which is both up-to-date and of high technical quality, is used by the ANA for its own initiatives.

A representative of JUASAVI commented on the aquifer recharge project implemented by the ANA as part of the Aquifer Management Plan for Ica, Villacurí and Lanchas:

What they [the ANA] are doing now with their recharge program is that they have taken part of our own recharge area, making it a comprehensive project, but only on paper because until now there has been no funding to execute what they have designed. We continue to clean the [irrigation] channels in order to supply those recharge areas, we hire the personnel, we recharge day and night the moment there is water. And all this is work done by the JUASVI. We have the systems to measure the water that enters, the water flows, the times; we work with SENAMHI (the national meteorological and hydrological agency) data on evaporation to effectively recharge. Because we are overseen by them (ANA), they obtain all the data, but it is work that is operatively and technically led and executed by JUASVI. And I say it in front of them all the time, because every time they can, they say "recharge and cleansing: this year (the aquifer) has been recharged..." and show our data. But they should say that it is work done by the JUASVI. When the Spanish hydro-geologist came, I went to Lima to the conference and he said "the work that the ANA has been doing." What's the job that the ANA has been doing? I say, oh my God! ... The ANA has the data because we give it to them and they sometimes use it as though it was their work, but they don' pay a single Sol for that work.

In a context where the techno-scientific approach to water is predominant, the agribusiness elite incorporates discourses around efficiency and rational use regarding their productive practices, thereby legitimizing themselves as the authoritative actor in order to establish a benchmark for water management. In a region like Ica where water stress exists, the efficiency discourse actually trivializes the problem, defining it not as the decrease in groundwater availability due to overexploitation by agribusiness, but rather as the consequence of inefficient irrigation practices carried out by small-scale farmers. In doing so, the agricultural export elite validates its right to control and uncontrollably consume underground and surface water in Ica.

\section{Coercive capacity}

Despite the creation of legal frameworks to protect the aquifer, the agribusiness elite has repeatedly circumvented regulations set by local water authorities and repressed attempts by ALA inspectors and civil society to monitor the situation. Since Chief 
Resolution $\mathrm{N}^{\circ} 330$ was passed in 2011, thereby ratifying a ban on the drilling of new boreholes in Ica and the prohibition of new underground water use rights in Villacurí and Lanchas, ALA officials have focused on detecting illegal drilling works, identifying nonregistered wells, and inspecting flow meters to verify the quantity of water being extracted. As a result, infringers have been issued fines up to S/. 3850 (approximately US\$1200) and unlawful wells have been closed.

As was the case of the water well surveys, the agricultural exporters have used their status as owners of large swathes of private property to prevent oversight by ALA personnel. This was the case, for example, when the state wanted to carry out a survey of water wells and was prevented from gaining access. As a result of their demands, previous notification is now required for control visits. Inspectors must give three days' notice before approaching the wells; a requirement that limits the ALA's capacity to sanction because some exporters reschedule the inspections indefinitely, while others benefit from the reminder to conceal the infractions.

In those few cases where surprise visits without explicit permission from the owners were carried out, the agribusinesses retaliated by initiating legal proceedings under the pretext of "abuse of authority." In many cases, these accusations turn into long legal disputes between actors with unequal different political and economic powers. In fact, claims of abuse of authority have become an institutionalized response from agribusinesses in an attempt to resist the regulation of groundwater use. As two ALA employees from Ica and Río Seco explain:

... there are workers who have received complaints in Rio Seco for sending a notification. They haven't even been allowed entry and yet they have been reported for abuse of authority, just for wanting to check things out. In the end, they never opened the doors, but they have reported us.

There is Benavides, Forsyth, Ventin, Joaquin Ormeño, a variety of people with political and economic power. And sometimes we, as an authority, have felt powerless clashing with them, not being able to act according to our duties. They shut their doors and we can't enter."

When inspectors have sanctioned infringers, the fines have been appealed in the Water Dispute Tribunal (Tribunal de Controversias Hídricas). During these appeals, agribusinesses have benefited from administrative errors made by civil servants or during the formulation of the indictment. A common outcome has been the reduction or cancellation of the fine. Figure 2 shows that of all the appeals between 2014 and 2016, in 70\% of cases the sanction established by the authorities was either reduced or cancelled.

Agricultural exporters claim that the use of violence is legitimate to defend private property. Inside and around their estates, the agricultural exporters rule. These spaces are walled and plastered with signs that warn trespassers about "orders to shoot." Gated checkpoints with private security restrict access to unauthorized wanderers. In this context, the ALA personnel are vulnerable to physical aggression while trying to carry out their duties. As one AAA Cháparra Chincha employee describes:

Many agricultural exporters are reluctant to allow the authorities to enter their property because they don't want to pay more. So we are currently using a different strategy; when access is denied we prepare a report, notify the infringer, and, meanwhile, take the precautionary measure of requesting the judge issues an entry order. We don't dare to enter and risk getting shot or beat up or reported for abuse of authority.

Fig. 2. Administrative proceeding appeals with published resolutions, 2014-2016. Source: Tribunal de Controversias Hídricas resolutions published on the ANA web site 2016. Prepared by the author.

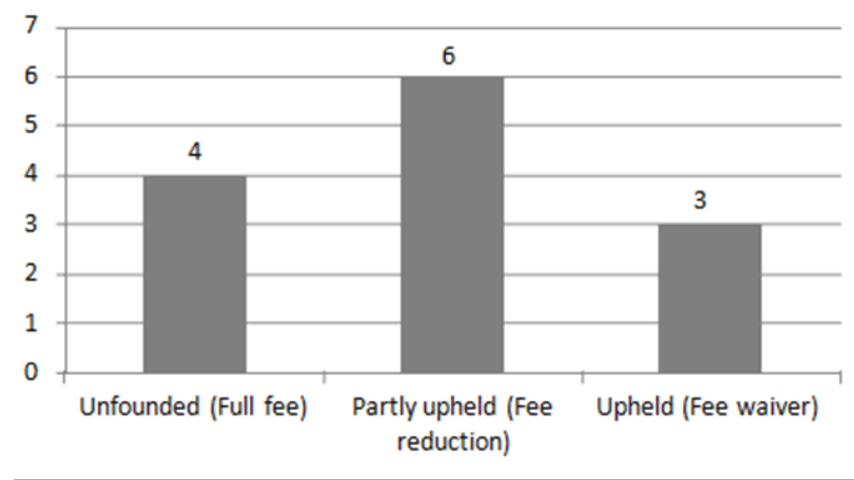

Through these tactics, government and civil society attempts to curb illegal overexploitation of groundwater resources in Ica and Villacurí are successfully subdued by the agribusiness elite under the guise of defending private property. Undoubtedly, the impossibility of regulating users or even encouraging their selfregulation contributes to the continuing depletion of the aquifer and to the accentuation of water scarcity across the region.

The capacity of the elite to exercise its hydrosocial power is tied to the stability of the political settlement it has established. Two trends may jeopardize this political coalition. On the one hand, the continued depletion and/or salinization of the aquifers would trigger severe water shortages and economic crisis. If this were to happen, agricultural export companies would migrate to other places while local actors would advocate for changes to current state policies. On the other hand, changes in political structures and functions of the state may result in modifications to the balance of power affecting the capacity of the elite to avoid state regulation, for example, if the environmental sector were to gain political influence thereby increasing its effectiveness in enforcing regulations. In any case, it is clear that without sufficient public regulation and scrutiny the political dominance of the agribusiness elite will continue to pose environmental and political risks.

\section{CONCLUSION}

In the case of Ica the political settlement between the agribusiness elite, key state sectors, and water user associations as minor partners has laid the foundation for the establishment of a politically and economically successful productive model based on the overexploitation of groundwater by the agribusiness elite.

The economic capacity of large agricultural export companies in Ica enables them to extract the water required to develop their 
business even in a semiarid environment where this resource is scarce. They have been able to occupy privileged locations to access the aquifer, purchase old wells or drill new ones, implement mechanized irrigation systems, extract groundwater with no proper regulation, and have even influenced the state to allocate its limited budget in support of infrastructure projects designed mainly to recharge the aquifers they are depleting. Under this extractive development model, large companies in Ica are able to expand their economic capacity regardless of social and environmental concerns.

Primarily, the agribusiness elite is able to influence political actions by employing a discourse around "water efficiency" that not only legitimizes its dominance but also obscures the fact that agricultural export companies are mainly responsible for water scarcity in the region. Several studies analyze the way technical knowledge around water has been used as a powerful instrument for political dominance (Worster 1985, Boelens and Doornbos 2001, Boelens and Vos 2012, Guevara 2013, Boelens 2014). In the Ica case, the agribusiness elite uses this knowledge-power to gain control over local resources and in particular to throw into question state capacity to effectively regulate groundwater extraction by agricultural export companies. This discourse is not imposed, but rather reproduced by the elite, the state, and WUAs; it is accepted as a truth and as such is a discourse of power.

In addition, the capacity of the elite to use repressive mechanisms enables them to evade oversight and regulation by the state regarding its use of groundwater resources. The privatization of the use of violence is not a new phenomenon but what is less common is that companies exercise the power of physical violence against government officials. The case of Ica also demonstrates the idea of the state as a fragmented entity and shows how private actors do not necessarily need to capture the entire state to subordinate its authority.

However, Ica is not a one-sided story in which the entrepreneurial elite captures the state (Durand 2016) or local actors struggle against corporations. In this article, I have presented a scenario where state sectors and water user associations accept the dominance of the agribusiness elite based on the shared neoliberal assumption that the agroexport private companies naturally have more financial and technical capacities to manage groundwater. Some discrepancy has been shown by representatives of local water authorities who try to exercise their regulatory functions but end up being coerced by the agribusinesses.

These findings contribute to ongoing discussions by showing how different and sometimes competing interests and political positions coexist inside the state (Migdal 1988, Corbridge et al. 2005, Chatterjee 2007) as well as how the predominance of the private sector can undermine state authority. Maintaining an ideological consensus with the state enables the agribusiness elite to do so in the name of economic development. This development model is not specific to Ica because similar examples can be found across Latin America (Yacoub et al. 2015). However, analyzing the Ica case provides new insights into this common story.

There is a considerable amount of literature, especially from a political ecology perspective, which analyzes the way private actors gain control over water resources (Worster 1985, Swyngedouw 2006, Bakker 2010, Wester and Hoogesteger 2011).
Some studies have investigated state or corporate mechanisms to achieve legitimacy at a local level (Bebbington 2009, Boelens et al. 2016, Swyngedouw and Boelens 2018). In particular Gustafsson (2018) has analyzed the strategies adopted by companies to legitimate their privileged access to resources and the negative long-term effects for state authority and governance. The findings in the Ica case study contribute to these debates by showing how under a specific political settlement elites can concentrate and exercise power by combining financial, technical knowledge and coercive strategies to legitimate control over local water resources. A political settlement that may collapse if groundwater resources are completely depleted and/or power balances inside state sectors change. Finally, the case of Ica shows how the concentration of power in private hands may foster production in the short term but can affect the authority of the state, thereby hindering evolution toward more democratic and institutionalized governance schemes, which would be required to guarantee the sustainable use of water resources.

${ }^{[1]}$ Ministry of Agriculture and Irrigation, 2011 press release, http://minagri.gob.pe/portal/notas-de-prensa/notas-de-prensa-2014/10719se-invertira-s-650-millones-para-ejecutar-obras-que-permitan-mantenerel-boom-agroexportador-de-ica

Responses to this article can be read online at: http://www.ecologyandsociety.org/issues/responses. php/10873

\section{Acknowledgments:}

I would like to offer my special thanks to the people of Ica who participated in this research. Also I would like to thank my colleagues María Mancilla García and Emilie Dupuits for their comments on early versions of this article.

\section{LITERATURE CITED}

Agrawal, A. 2005. Environmentality: technologies of government and the making of subjects. Duke University Press, Durham, North Carolina, USA.

Autoridad Nacional del Agua (ANA). 2018. Plan de Gestión del acuifero del valle de Ica y pampas de Villacurí y Lanchas. Ministerio de Agricultura y Riego, Lima, Peru. [online] URL: http://www. ana.gob.pe/media/528051/ica $\% 20-\% 20$ plan $\% 20$ de $\% 20$ gesti $\%$ C $3 \%$ B3n.pdf

Bakker, K. 2010. Privatizing water. Governance failure and the world's urban water crisis. Cornell University Press, Ithaca, New York, USA. https://doi.org/10.7591/9780801463617

Bebbington, A. 2009. Extractive industries and stunted states: conflict, responsibility and institutional change in the Andes. Pages 97-115 in R. Raman, editor. Corporate social responsibility: discourses, practices and perspectives. Palgrave MacMillan, London, UK.

Bebbington, A., A. Abdulai, M. Hinfelaar, D. Bebbington, and C. Sanborn. 2017. Political settlements and the governance of 
extractive industry: a comparative analysis of the longue durée in Africa and Latin America. ESID Working Paper No. 81. University of Manchester, Manchester, UK. [online] URL: http:// www.effective-states.org/wp-content/uploads/working_papers/finalpdfs/esid wp 81 bebbington et al.pdf https://doi.org/10.2139/ $\underline{\text { ssrn.2986786 }}$

Bebbington, A., and M. N. Williams. 2008. Water and mining conflicts in Peru. Mountain Research and Development 28 (3):190-195. https://doi.org/10.1659/mrd.1039

Bichsel, C. 2016. Water and the (infra-)structure of political rule: A synthesis. Water Alternatives 9(2):356-372.

Boelens, R. 2011. Luchas y defensas escondidas: pluralismo legal y cultural como una práctica de resistencia creativa en la gestión local del agua en los Andes. Anuario de Estudios Americanos 68 (2):673-703. https://doi.org/10.3989/aeamer.2011.v68.i2.554

Boelens, R. 2014. Cultural politics and the hydrosocial cycle: water, power and identity in the Andean highlands. Geoforum (57):234-247. https://doi.org/10.1016/j.geoforum.2013.02.008

Boelens, R. and B. Doornbos. 2001. The battlefield of water rights: rule making amidst conflicting normative frameworks in the Ecuadorian highlands. Human Organization (60):343-355. https://doi.org/10.17730/humo.60.4.d3v194qmcael7ett

Boelens, R., D. Getches, and A. Guevara-Gil. 2006. Agua y derecho: politicas hídricas, derechos consuetudinarios e identidades locales. Instituto de Estudios Peruanos, Lima, Peru.

Boelens, R., J. Hoogesteger, E. Swyngedouw, J. Vos, and P. Wester. 2016. Hydrosocial territories: a political ecology perspective. Water International. 41(1):1-14. https://doi.org/10.1080/025080$\underline{60.2016 .1134898}$

Boelens, R., and J. Vos. 2012. The danger of naturalizing water policy concepts: water productivity and efficiency discourses from field irrigation to virtual water trade. Agricultural Water Management (108):16-26. https://doi.org/10.1016/j.agwat.2011.06.013

Bourdieu, P., and J. C. Passeron. 2001. La Reproducción. Elementos para una teoría del sistema de enseñanza. Libro 1, Madrid, Spain. Editorial Popular.

Budds, J., J. Linton, and R. McDonnell. 2014. Editorial: the hydrosocial cycle. Geoforum 57:167-169. https://doi.org/10.1016/ j.geoforum.2014.08.003

Chatterjee, P. 2007. La nación en tiempo heterogéneo y otros estudios subalternos. Instituto de Estudios Peruanos, The SouthSouth Exchange Proramme for Research on the History of Development, Consejo Latinoamericano de Ciencias Sociales, Lima, Peru.

Corbridge, S., G. Williams, M. Srivastava, and R. Véron. 2005. Seeing the state: governance and governmentality in India. Cambridge University Press, Cambridge, UK. https://doi. org/10.1017/CBO9780511492211

Damonte, G. 2015. Redefiniendo territorios hidrosociales: control hídrico en el valle de Ica, Perú (1993-2013). Cuadernos de Desarrollo Rural 12(76):109-133. http://dx.doi.org/10.11144/ Javeriana.cdr12-76.rthc
Damonte, G., and R. Boelens. 2019. Hydrosocial territories, agroexport and water scarcity: capitalist territorial transformations and water governance in Peru's coastal valleys. Water International, in press.

Damonte, G., and I. Gonzales. 2018. Política Pública, Relaciones de Poder y Conflicto de Intereses en la Gestión del Agua en Ica. Pages 75-112 in M. T. Oré and I. Muñoz, editors. Aguas en Disputa: Ica y Huancavelica, entre el entrampamiento y el diálogo. Fondo Editorial Pontificia Universidad Católica del Perú, Lima, Peru.

Damonte, G., E. Pacheco, and C. Grados. 2014. Dinámicas de concentración y escasez de agua: el boom agroexportador y los pequeños propietarios en las zonas medias y altas del río Ica. Pages 127-172 in M. T. Oré and G. Damonte, editors. ¿Escasez de agua?: Retos para la gestión de la cuenca del río Ica. Pontificia Universidad Católica del Perú, Lima, Peru.

Davies, M. I. J. 2009. Wittfogel's dilemma: heterarchy and ethnographic approaches to irrigation management in eastern Africa and Mesopotamia. World Archaeology 41(1):16-35. https:// doi.org/10.1080/00438240802666465

Department for International Development (DFID). 2010. Building peaceful states and societies. DFID, London, UK.

Duarte-Abadía, B., R. Boelens, and T. Roa-Avendaño. 2015. Hydropower, encroachment and the re-patterning of hydrosocial territory: the case of Hidrosogamoso in Colombia. Human Organization 74(3):243-254. https://doi.org/10.17730/0018-7259-74.3.243

Durand, F. 2016. Cuando el poder extractivo captura el estado. Lobbies, puertas giratorias y paquetazo ambiental en Perú. Oxfam, Lima, Peru.

Durand, F. 2018. Odebrecht: la empresa que capturaba gobiernos. Fondo Editorial Pontificia Universidad Católica del Perú, Lima, Peru.

Foucault, M. 1992. El orden del discurso. Tusquets, Buenos Aires, Argentina.

Foucault, M. 2006. Governmentality. Pages 131-143 in A. Sharma and A. Gupta, editors. The anthropology of the state. Blackwell, Malden, Maine, USA.

Guevara, A. 2013. El derecho y la gestión local del agua en Santa Rosa de Ocopa, Junín, Perú. Instituto de Promoción para la Gestión del Agua, Lima, Peru.

Gustafsson, M.-T. 2018. Private politics and peasant mobilization. Mining in Peru. Palgrave-Macmillan, London, UK. https://doi. org/10.1007/978-3-319-60756-6

Hendriks, J., and R. Boelens. 2016. Acumulación de derechos de agua en el Perú. Anthropologica 34(37):13-32. https://doi. org/10.18800/anthropologica.201602.001

Hoogesteger, J., R. Boelens, and M. Baud. 2016. Territorial pluralism: water users' multi-scalar struggles against state ordering in Ecuador's highlands. Water International 41 (1):91-106. https://doi.org/10.1080/02508060.2016.1130910

Hoogesteger, J., and A. Verzijl. 2015. Grassroots scalar politics: insights from peasant water struggles in the Ecuadorian and 
Peruvian Andes. Geoforum 62:13-23. https://doi.org/10.1016/j. geoforum.2015.03.013

Hommes, L., and R. Boelens. 2017. Urbanizing rural waters: rural-urban water transfers and the reconfiguration of hydrosocial territories in Lima. Political Geography 57:71-80. https://doi.org/10.1016/j.polgeo.2016.12.002

Instituto Nacional de Estadística e Informática (INEI). 1994. III Censo nacional agropecuario. INEI, Lima, Peru. [online] URL: http://censos.inei.gob.pe/bcoCuadros/IIIcenagro.htm

Instituto Nacional de Estadística e Informática (INEI). 2012. IV Censo nacional agropecuario. INEI, Lima, Peru. [online] URL: http://censos.inei.gob.pe/Cenagro/redatam/

John, J. D., and J. Putzel. 2009. Political settlements. GSDRC, University of Birmingham, Birmingham, UK.

Khan, M. H. 2000. Rent-seeking as process. Pages 70-144 in M. H. Khan, and K. S. Jomo, editors. Rents, rent-seeking and economic development: theory and evidence in Asia. Cambridge University Press, Cambridge, UK. https://doi.org/10.1017/ CBO9781139085052.003

Livingstone, D. N. 2011. Environmental determinism. Pages 368-380 in J. A. Agnew and D. N. Livingstone, editors. The $S A G E$ handbook of geographical knowledge. SAGE, London, UK. https://doi.org/10.4135/9781446201091.n28

Marshall, A. 2014. Apropiarse del desierto: Agricultura globalizada y dinámicas socioambientales en la costa peruana. Instituto de Estudios Franceses, Lima, Peru.

Matos, J., and J. Mejia. 1980. La reforma Agraria en el Perú. Instituto de Estudios Peruanos, Lima, Peru.

Migdal, J. S. 1988. Strong societies and weak states: state-society relations and state capabilities in the Third World. Princeton University Press, Princeton, New Jersey, USA.

Mitchell, W. P. 1973. The hydraulic hypothesis: a reappraisal. Current Anthropology 14(5):532-534. https://doi.org/10.1086/201379

Muñoz, I. 2015. Adaptación y debilidad del Estado: El caso de la escasez de agua subterránea en Ica. Revista de Ciencia Política y Gobierno 3(4):47-68.

Oré, M. T. 2006. Agua, bien común y usos privados. Estado, riego y conflictos en La Achirana del Inca. Segunda edición. Fondo Editorial Pontificia Universidad Católica del Perú, Lima, Peru.

Oré, M. T., D. Bayer, J. Chiong, and E. Rendón. 2012. La guerra por el agua en Ica, Perú. El colapso del agua subterránea. Pages 149-166 in E. Isch, R. Boelens, and F. Peña, editors. Agua, injusticia y conflictos. Instituo de Estudios Peruanos, Pontificia Universidad Católica del Perú, Justicia Hídrica, Centro Bartolomé de las Casas, Lima, Peru.

Oré, M. T., and G. Damonte, editors. 2014. ¿Escasez de agua? Retos para la gestión de los recursos hídricos en la cuenca del río Ica. Pontificia Universidad Católica del Perú, Lima, Peru.

Oré, M. T., and D. Geng. 2014. Políticas públicas del agua en las regiones: las viscisitudes para la creación del Consejo de Recursos Hídricos de la cuenca Ica-Huancavelica. Pages 269-312 in G. Damonte and M. T. Oré, editors. ¿Escasez de agua? Retos para la gestión de los recursos hídricos en la cuenca del río Ica. Pontificia Universidad Católica del Perú, Lima, Peru.

Oré, M. T., and I. Muñoz, editors. 2018. Aguas en Disputa: Ica y Huancavelica, entre el entrampamiento y el diálogo. Fondo Editorial Pontificia Universidad Católica del Perú, Lima, Peru.

Peña, F. 2011. Acumulación de derechos de agua en México: el poder de las élites. Pages 209-224 in R. Boelens, L. Cremers, and M. Zwarteveen, editors. Justicia hídrica. Acumulación, conflicto y acción social. Instituto de Estudios Peruanos, Fondo Editorial, Pontificia Universidad Católica del Perú, Lima, Peru.

Perreault, T. 2007. De la 'guerra del agua' a la 'guerra del gas': gobernabilidad de recursos, neoliberalismo, y protesta popular en Bolivia. Pages 147-182 in C. Crespo and S. Spronk, editors. Después de las guerras del agua en Bolivia. CESU-UMSS/Plural Editores, La Paz, Bolivia.

Perreault, T. 2013. ¿Despojo por acumulación? Minería, agua y justicia social en el Altiplano boliviano. Pages 187-205 in A. Arroyo and R. Boelens, editors. Aguas robadas: despojo hídrico y movilización social. Abya Yala/IEP, Quito, Ecuador.

Sanborn, C., T. Ramírez, and V. Hurtado. 2017. Mining, political settlements and inclusive development in Peru. ESID Working Paper No. 79. University of Manchester, Manchester, UK. https://doi.org/10.2139/ssrn.2963665

Springer, S. 2012. Neoliberalising violence: of the exceptional and the exemplary in coalescing moments. Area 44:136-143. https:// doi.org/10.1111/j.1475-4762.2012.01084.x

Swyngedouw, E. 2004. Social power and the urbanization of water: flows of power. Oxford University Press, Oxford, UK.

Swyngedouw, E. 2006. Power, water and money: exploring the nexus. Human Development Occasional Papers. 2006/14. Human Development Report Office, United Nations Development Programme, New York, New York, USA.

Swyngedouw, E., and R. Boelens. 2018. “... And not a single injustice remains": hydro-territorial colonization and technopolitical transformations in Spain. Pages 115-133 in R. Boelens, T. Perreault, and J. Vos, editors. Water justice. Cambridge University Press, Cambridge, UK. https://doi.org/10.1017/9781$\underline{316831847.008}$

Urteaga-Crovetto, P. 2016. Between water abundance and scarcity: discourses, biofuels, and power in Piura, Peru. Antipode. A Radical Journal of Geography 48(4):1059-1079. https://doi. org/10.1111/anti.12234

Valz-Gen, G. 2017. Fernando Cillóniz: "No estoy interesado en un segundo periodo." El Comercio, 13 February. [online] URL: https://elcomercio.pe/peru/ica/fernando-cilloniz-interesado-segundoperiodo-164066

Wester, P., and J. Hoogesteger. 2011. Uso intensivo y despojo del agua subterránea: hacia una conceptualización de los conflictos y la concentración del acceso al agua subterránea. Pages 111-134 in R. Boelens, L. Cremers, and M. Zwarteveen, editors. Justicia hídrica: Acumulación, conflicto y acción social. Instituto de Estudios Peruanos, Lima, Peru. 
Wittfogel, K. A. 1957. Oriental despotism: a comparative study of total power. Yale University Press, New Haven, Connecticut, USA.

Worster, D. 1985. Rivers of empire: water, aridity, and the growth of the American West. Pantheon Books, New York, New York, USA.

Yacoub, C., B. Duarte, and R. Boelens. 2015. Reflexiones: despojo del agua e hidroeléctricas. Pages 263-303 in B. Duarte, R. Boelens, and C. Yacoub, editors. Agua y Ecología. El extractivismo en la agroexportación, la minería y las hildroeléctricas en Latinoamérica. Abya Yala, Quito, Ecuador. 